\title{
The Interaction between Convergent and Divergent Approaches of Global Law in the Field of Business and Human Rights
}

\author{
La interacción entre los enfoques convergentes \\ y divergentes del derecho global en el ámbito \\ de las empresas y los derechos humanos
}

\section{Linteraction entre les approches convergentes et divergentes du droit mondial dans le domaine des entreprises et droits de l'homme}

\section{Alejandro Sánchez González*}

\begin{abstract}
SummarY: I. Introduction. II. Conceptual Framework. III. Convergent and Divergent Approaches of Global Law in the Field of Business and Human Rights. IV. The Compatibility and Interaction between Divergent and Convergent Approaches of Global Law in the Field of Business and Human Rights. V. Conclusions. VI. Bibliography.
\end{abstract}

* Universidad de Monterrey, México; ORCID ID: https: / /orcid.org/0000-0003-1712-0001, alejandro@herediasanchez.mx. 
RESUMEN: Las nociones convergentes buscan contrarrestar la diferencia tratando al derecho global como un acuerdo colectivo implementado por arreglos jerárquicos. Por el contrario, las concepciones divergentes buscan gestionar la diferencia a través de la coordinación de distintos órdenes normativos. Existe un amplio debate sobre las discrepancias entre estos enfoques, pero poco se ha dicho sobre sus afinidades. Así, el propósito de este texto es analizar ambas visiones, utilizando el campo de las empresas y los derechos humanos como caso de estudio. Al hacerlo, demostraremos que las nociones convergentes y divergentes son compatibles y capaces de interactuar en beneficio recíproco, estableciendo relaciones de aprendizaje, manteniendo sus propias condiciones de existencia y colaborando en conjunto para el logro de objetivos comunes.

Palabras clave: derecho global, enfoque convergente, enfoque divergente, empresas y derechos humanos.

ABSTRACT: Convergent notions seek to counter difference by treating global law as a collective agreement implemented by hierarchical arrangements. By contrast, the divergent conceptions seek to manage difference through the coordination of distinct normative orders. There is an ample debate around the discrepancies between these two approaches, but little has been said about their affinities. Thus, the purpose of this text is to analyze both visions, utilizing the field of business and human rights as a case study. By doing so, we will prove that convergent and divergent notions are compatible and capable to interact for reciprocal benefit, by establishing learning relationships, by maintaining the conditions of existence of one another, and by collaborating as a whole to achieve common objectives.

Key words: global law, convergent approach, divergent approach, business and human rights.

RÉSUMÉ: Les notions convergentes cherchent à contrer la différence en traitant le droit mondial comme une convention collective mise en ouvre par des accords hiérarchiques. Au contraire, les conceptions divergentes cherchent à gérer la différence par la coordination d'ordres normatifs distincts. Il existe un vaste débat autour des divergences entre ces deux approches, mais peu a été dit sur leurs affinités. Donc, le but de ce texte est d'analyser les deux visions, en utilisant le domaine des entreprises et des droits de l'homme comme étude de cas. Ce faisant, nous prouverons que les notions convergentes et divergentes sont compatibles et capables d'interagir pour un bénéfice réciproque, en établissant des relations d'apprentissage, en maintenant les conditions d'existence les unes des autres et en collaborant dans leur ensemble pour atteindre des objectifs communs.

Mots-clés: droit mondial, approche convergente, approche divergente, entreprises et droits de l'homme. 


\section{INTRODUCTION}

In his book, Intimations of Global Law, Neil Walker ${ }^{1}$ highlights the distinction between two conceptions of global law: legal convergence and legal divergence. ${ }^{2}$ Regarding the first one, this author affirms that convergent notions seek to counter or overcome difference by treating global law as the object of a collective agreement, which involves a vertical arrangement of authoritative global rule-making or rule-application. ${ }^{3}$ As well, concerning the second approach, Neil Walker asserts that divergence-accommodating conceptions seek to manage difference by employing global law as a means of tracking, harnessing and confining diversity, which involves a horizontal framework of co-ordination of different regimes or normative orders. ${ }^{4}$

There has been an ample debate around the differences between convergent and divergent approaches of global law, but little has been said about their coincidences and the way they can interact to address the increasing complexity of the post-national legal landscape. Consequently, the purpose of this piece is to analyze these two conceptions of global law through a theoretical-correlational method, and utilizing the field of business and human rights as a case study. After doing so, we will arrive to the conclusion that convergent and divergent approaches are not only compatible, but they are also capable to interact for reciprocal benefit, by establishing learning relationships, by creating and maintaining the conditions of existence of one another, and by collaborating as a whole to achieve common objectives.

To support this conclusion, in chapter II, we will study the concepts of global law, legal convergence and legal divergence. In chapter III, we will review the different regulatory initiatives that have been proposed in the field of business and human rights and we will point out their convergent or divergent features. Finally, in chapter IV, we will demonstrate the compatibility of these two approaches and identify how they have been interacting through reciprocal reinforcing relations.

1 Scottish lawyer and professor at the School of Law of the University of Edinburgh.

2 Walker, Neil, Intimations of Global Law, Cambridge, Cambridge University Press, 2014, p. 55 .

\footnotetext{
3 Idem.

4 Idem.
} 


\section{CONCEPTUAL FRAMEWORK}

What do we mean when we talk about global law? Several definitions can be proposed, depending on which specific characteristic of this concept one wants to emphasize. However, broadly speaking, we can say that global law refers to a general endorsement or commitment to some rules and standards at the planetary level. ${ }^{5}$ In this sense, there is no territorial limit to the jurisdiction of global law, as it rests on a flexible notion of state sovereignty, in which the boundaries between the national and the international are porous and blurred.

But is it possible to obtain universal consensus on a particular matter? Is it feasible that all countries in the world agree on and abide by concrete norms, despite their political, economic, and cultural differences? If this is so, which is the best way to achieve this level of compromise? And more important, which is the most effective alternative to ensure compliance with those obligations once they are created?

The answers to these questions are still under debate. In general terms, and with varying nuances, the spectrum of this discussion has transited between two different conceptions of global law: legal convergence and legal divergence. ${ }^{6}$ In the following sections, we will identify the principal characteristics of each of these visions.

\section{Convergent Approach of Global Law}

From a convergent standpoint, global law is conceived as the result of a collective agreement. Therefore, it is based on the voluntary commitments of the states, which are captured in international treaties and conventions. ${ }^{7}$

5 Idem.

6 Idem. With some modulation, these notions also encompass the distinction between integrated and fragmented international law, as Martti Koskenniemi and the Study Group of the International Law Commission discern in: United Nations, General Assembly, "Fragmentation of International Law: Difficulties Arising from the Diversification and Expansion of International Law", Report of the Study Group of the International Law Commission, A/CN.4/L.682, 13 April 2006.

7 Ibidem, p. 58. 
As well, this notion tends to conceive global law as an integrated, all-encompassing and systematized set of rules, which pulls towards a common normative direction. ${ }^{8}$ Thus, global law is mostly composed of hard law, that is, legally binding obligations with their correspondent enforceable rights and duties. ${ }^{9}$ In this sense, a convergent approach involves the conformation of vertical and hierarchical structures, to produce and enforce global law, as it operates in a pyramidal, top-down fashion. ${ }^{10}$

One example of a convergent approach of global law can be found in the traditional UN system. This supranational organization is composed exclusively by states, whose agreements produce rules and standards, mainly, through binding treaties that become the higher law. ${ }^{11}$ As well, the core institutions of the UN, namely, the General Assembly, the Security Council, the Human Rights Council, and the several monitoring treaty-bodies, operate with a highly normative authority upon the states. ${ }^{12}$ This is why the UN system can be considered as a prototype of global law, and as a reference to be replicated in the different fields of international law.

However, the UN system is not exempt from limitations. One of the most important, is that its membership is limited to states alone, leaving aside international organizations and transnational corporations, among other relevant actors. ${ }^{13}$ As well, as it is based on voluntary commitments, if one state is not a member of the UN, or if a member does not ratify a particular treaty, there is not much that can be done to regulate its behavior. ${ }^{14}$ Moreover, and despite their vertical structure, the monitoring committees have not achieved widespread compliance with the obligations established in the UN treaties and conventions. ${ }^{15}$

Furthermore, as Gráinne de Búrca, Robert Keohane and Charles Sabel assert, the convergent vision of global law is a very stiff model of governan-

8 Ibidem, p. 59.

9 Choudhury, Barnali, "Balancing Soft and Hard Law for Business and Human Rights", International and Comparative Law Quarterly, Cambridge, vol. 67, no. 4, 2018, p. 963.

10 Walker, Neil, op. cit., p. 55.

11 Ibidem, p. 62.

12 Ibidem, p. 60.

13 Ruggie, John Gerard, "Global Governance and New Governance Theory: Lessons from Business and Human Rights", Global Governance, Boston, vol. 20, 2014, p. 8.

14 Walker, Neil, op. cit., p. 62.

15 Ruggie, John Gerard, “Global Governance...”, op. cit., p. 8. 
ce. ${ }^{16}$ Consequently, it cannot be easily adapted to new circumstances, since the generation and modification of the law depend on the consensus of the countries, which is difficult to achieve. ${ }^{17}$ Therefore, it can rapidly become obsolete and increase the gaps between regulation and the issues that it intends to solve. ${ }^{18}$

Likewise, these scholars argue that the creation of convergent modes of governance is becoming increasingly difficult. ${ }^{19}$ In the past, general consensus on a particular matter was almost imposed by western powers to weaker states. ${ }^{20}$ However, today we are experiencing a shift in the global power dynamics, marked by the rising of new strong countries, such as China, India, Brazil, Russia and South Africa, which support other developing countries. Consequently, nowadays it is not simple to achieve universal agreement in the international arena, especially on contested topics. ${ }^{21}$

For these reasons, as a response to the rigid, state-centered, hierarchical and binding approach, divergent notions of global law have been developed. Let us analyze the main characteristics of these visions.

\section{Divergent Approach of Global Law}

Traditionally, domestic legal systems are based on a constitution, which represents the exclusive source and the primordial validity criterion of any other law. Consequently, when people think about global law, they tend to imagine a top-down structure, similar to national constitutionalism and to the convergent approach that we have just analyzed. ${ }^{22}$ Nevertheless, if one reviews the existing international regulations, the framework that appears is quite diverse. ${ }^{23}$

16 Búrca, Gráinne de et al., "New Modes of Pluralist Global Governance", NewYork University Journal of International Law and Politics, New York, vol. 45, no. 1, 2013, p. 729.

17 Idem.

18 Ibidem, p. 735.

19 Ibidem, p. 736.

20 Idem.

21 Idem.

22 Krisch, Nico, "Pluralism in Postnational Risk Regulation: The Dispute over GMOs and Trade”, Transnational Legal Theory, London, vol. 1, 2010, p. 1.

23 Idem. 
In a globalized world, it is inevitable for states and non-state actors to face different obligations, which are originated by several treaties and other sources of international law. ${ }^{24}$ For this reason, nowadays we are immersed in a plural and fragmented order, conformed by many different regimes that tend to regulate specific fields of international law, such as trade, investment, environment, human rights, among others. ${ }^{25}$ However, oftentimes the scope of one regime overlaps with the regulatory field of another, so they duplicate functions and compete for authority. ${ }^{26}$ As well, the different international regimes also connect with the domestic and regional regulations that address the same issues. ${ }^{27}$ Therefore, two types of pluralism can be identified. ${ }^{28}$ Firstly, a horizontal type, which is marked by the coexistence and competition between different international regimes ${ }^{29}$ and secondly, a vertical type, characterized by the interaction of the international, regional and national legal systems. ${ }^{30}$ Consequently, what we have in reality is not an integrated and organized structure, but rather a regime complex, that is, an array of overlapping and fragmented regimes that govern a particular area, with no overarching rules to clarify, delimit and define their interaction. ${ }^{31}$

In this sense, divergent approaches of global law are not based on the idea of a singular legal order that operates hierarchically, as the convergent visions propose. Conversely, divergent notions of global law are focused on the organization and alignment of the different regimes that coexist in a

24 Klabbers, Jan and Trommer, Silke, "Peaceful Coexistence: Normative Pluralism in International Law”, in Klabbers, Jan and Piiparinen, Touko (eds.), Normative Pluralism and International Law: Exploring Global Governance, Cambridge, Cambridge University Press, 2013, p. 67.

25 Krisch, Nico, op. cit., p. 9.

26 Idem.

27 Ibidem, p. 13.

28 Nollkaemper, Andre, "Inside or Out: Two Types of International Legal Pluralism”, in Klabbers, Jan and Piiparinen, Touko (eds.), Normative Pluralism and International Law: Exploring Global Governance, Cambridge, Cambridge University Press, 2013, p. 94.

${ }_{29}$ Krisch, Nico, op. cit., p. 9

30 Ibidem, p. 13.

31 Bodansky, Daniel, “Climate Change: Transnational Legal Order or Disorder?”, in Halliday, Terrence and Shaffer, Gregory (eds.), Transnational Legal Orders, Cambridge, Cambridge University Press, 2015, p. 301. 
plural and heterarchical context, ${ }^{32}$ as well as in the mutually reinforcing relations that can be built between each other. ${ }^{33}$

Additionally, unlike convergent visions of global law, divergent approaches are open to engage with non-state actors and to complement hard law regulation with soft law initiatives, that is, with non-binding principles, guidelines and standards that, despite their lack of enforceability, can create social expectations and modify behaviors. ${ }^{34}$ These alternatives are based on the idea that the primordial condition for the existence of a law is not enforcement, but rather the shared understanding of the expected conducts. ${ }^{35}$ In this sense, divergent approaches of global law are very flexible and adaptable to change. Therefore, they are especially useful in circumstances where generalized consensus cannot be obtained, or when governments are reluctant to accept binding obligations. ${ }^{36}$ In such cases, a divergent approach, even in the form of soft law, is preferable to no regulation at all. ${ }^{37}$

Nevertheless, the effectiveness of divergent notions of global law is contested due to its softness and, consequently, its inability to alter the behavior of the states. What substantive changes can be obtained if compliance with international standards depends on the promises and goodwill of the states and other international actors? How can non-binding responsibilities be stronger than obligations with full normative content? In which way can a horizontal and heterarchical framework be more effective than a vertical and hierarchical structure? In the following sections of this essay, we will address these questions, using the field of business and human rights as a case study. Our objective is to move beyond the convergent-divergent debate, as if they were mutually excluding approaches, and demonstrate not only that they can coexist, but also how they interact and the positive results that can be obtained through such interaction.

32 Búrca, Gráinne de et al., "New Modes of Pluralist...", op. cit., p. 730. And this is perhaps the specific difference between divergent notions (as a genre) and fragmentation (as one of its species). While fragmentation relates, mainly, to the emergence of different specialized and autonomous systems, divergence seeks the coordination of such systems.

33 Rodríguez Garavito, César, "The Future of Human Rights: From Gatekeeping to Symbiosis”, SUR International Journal on Human Rights, São Paulo, vol. 11, no. 20, 2014, p. 500.

34 Choudhury, Barnali, op. cit., p. 963.

35 Brunnée, Jutta and Toope, Stephen, Legitimacy and Legality in International Law: An Interactional Account, Cambridge, Cambridge University Press, 2010, p. 335.

36 Idem.

37 Ibidem, p. 964. 


\section{CONVERGENT AND DivergENT APPROACHES OF GLOBAL LAW IN THE FIELD OF BUSINESS AND HUMAN RigHTS}

Traditionally, human rights are conceived as barriers to the exercise of public power, only opposable against the state. ${ }^{38}$ However, this notion has changed, since other actors, such as private corporations, have recently acquired significant power, which represents a threat to fundamental freedoms. ${ }^{39}$ Consequently, there have been several attempts to regulate the behavior of business enterprises in regards to human rights, and minimize the adverse impacts that the commercial activities can have on workers, communities and the environment. ${ }^{40}$

Since the 1970s, the UN has tried to create regulation to address this issue. ${ }^{41}$ As well, other international organizations, such as the Organization for Economic Cooperation and Development (OECD) and the International Labor Organization (ILO) have put into effect guidelines and principles on this same subject matter. ${ }^{42}$ These initiatives have been complemented by the UN program of the Global Compact, ${ }^{43}$ and with the failed proposal of the Norms on the Responsibilities of Transnational Corporations and other Business Enterprises with Regard to Human Rights (the Norms). ${ }^{44}$

38 Weissbrodt, David and Kruger, Muria, "Human Rights Responsibilities of Business as Non-State Actors”, in Alston, Philip (ed.), Non-State Actors and Human Rights, Oxford, Oxford University Press, 2005, p. 315.

39 Alston, Philip, “The Not-A-Cat Syndrome: Can the International Human Rights Regime Accommodate Non-State Actors?”, in Alston, Philip (ed.), Non-State Actors and Human Rights, Oxford, Oxford University Press, 2005, p. 3.

40 Weissbrodt, David and Kruger, Muria, op. cit., p. 318.

41 Such as the United Nations Code of Conduct on Transnational Corporations, adopted by resolution of the UN Economic and Social Council in 1974.

42 Namely, the OECD Guidelines for Multinational Enterprises, and the ILO Tripartite Declaration of Principles concerning Multinational Enterprises, which was complemented in 1998 with the Declaration of Fundamental Principles and Rights at Work.

43 A voluntary initiative to encourage companies to embrace ten principles concerning environmental protection, anti-corruption strategies and international human rights. For more information, see United Nations, "Global Compact", 2020, available at: https: / /www.unglobal compact.org/.

44 A mandatory standard applicable to all corporations, that did not obtain the endorsement from the UN Commission on Human Rights. 
The case of the Norms is of particular salience, since they were drafted in a very convergent fashion, with the intent of imposing multiple binding obligations upon all kinds of corporations, whose compliance would be monitored by different mechanisms. ${ }^{45}$ Nevertheless, by the time they were discussed by the UN Commission on Human Rights (currently the UN Human Rights Council) they were rejected because they were considered unnecessary, overreaching and too binding. ${ }^{46}$

In this sense, the convergent approach of the Norms determined its failure. For this reason, when John Gerard Ruggie was appointed as a special representative of the UN Secretary-General (SRSG), with the mandate of developing a regulatory framework concerning business and human rights, he decided to adopt a divergent approach. By doing so, he achieved the endorsement of the Guiding Principles on Business and Human Rights (GPs) by the UN Human Rights Council. ${ }^{47}$ In the following section, we will briefly analyze the GPs to identify their divergent characteristics.

\section{The Divergent UN Guiding Principles on Business and Human Rights}

Taking into account that the Norms were discarded by the UN, mainly, because of their convergent character, the SRSG developed a divergent initiative, in the form of soft law, ${ }^{48}$ which did not involve the creation of new international obligations. ${ }^{49}$ On the contrary, the GPs were based on existing international and national law, as well as on the implementation of due diligence processes within the corporations. ${ }^{50}$

45 Alston, Philip and Goodman, Ryan, International Human Rights, Oxford, Oxford University Press, 2013, p. 1468.

46 Idem. Apart from being binding, it is because of the stiff and vertical scaffolding proposed by the Norms, that they can be characterized within the convergent approach.

47 Ruggie, John Gerard, Just Business: Multinational Corporations and Human Rights, New York, Norton and Company, 2013, p. xi.

48 Although soft law is a tool widely used within the divergent approach, it only represents one of its possible elements, as divergent notions promote the alignment of different regimes, that can be configured by hard or soft law, as well as public and corporate governance both in the international and national level.

49 Ruggie, John Gerard, Just Business..., cit., p. xii.

50 Ibidem, p. xxii. 
This structure was proposed by the SRSG because he realized that the behavior of business enterprises was determined by three different systems of regulation: public governance (international and national law), corporate governance (codes of conduct and management processes) and civil governance (social expectations and social mobilization). ${ }^{51}$ Therefore, to modify the conduct of corporations it was necessary to align these three systems of regulation towards the same objective: the safeguard of human rights. ${ }^{52}$

To this effect, the SRSG developed the Protect, Respect and Remedy Framework..$^{53}$ The verb protect is addressed to the states and is related to public governance, that is, to the compliance with international and national regulations. ${ }^{54}$ Hence, according to the GPs, the states have the obligation to protect human rights against violations from any third party, including corporations. ${ }^{55}$ For its part, the verb respect is directed to corporations, to which the SRSG vested the non-binding responsibility to respect human rights. To this effect, every company should avoid human rights violations by identifying risks and adopting due diligence processes to minimize them. ${ }^{56}$ Finally, the state and the corporations must ensure effective remedy for the victims of human rights violations through legal procedures, mediation mechanisms and private agreements. ${ }^{57}$

In this sense, as César Rodríguez Garavito asserts, the GPs should be understood in two dimensions. ${ }^{58}$ First, the static dimension of the GPs refers to the rules and standards that are expressed in the document. ${ }^{59}$ Second, the dynamic dimension is characterized by new regulatory strategies that can be built upon the GPs, to ensure that corporations will comply with their duties. ${ }^{60}$ Consequently, another divergent feature of the GPs is that they are

51 Ibidem, p. 78.

52 Idem.

53 United Nations Guiding Principles on Business and Human Rights (2011), general principles.

54 Ibidem, principle 1

55 Idem.

56 Ibidem, principle 15.

57 Ibidem, principle 26.

58 Rodríguez Garavito, César, "Business and Human Rights: Beyond the End of the Beginning”, in Rodríguez Garavito, César (ed.), Business and Human Rights: Beyond the End of the Beginning, Cambridge, Cambridge University Press, 2017, p. 11.

59 Idem.

60 Idem. 
not a fixed document. ${ }^{61}$ On the contrary, they represent an ongoing process that is in constant interrelation with different regulatory systems. ${ }^{62}$

Consequently, the current regulation of the field of business and human rights is informed by a divergent approach, due to the following reasons:

- First, within a horizontal type of pluralism, ${ }^{63}$ the UN GPs coexist in a heterarchical way with other international initiatives, such as the OECD Guidelines for Multinational Enterprises, the ILO Tripartite Declaration and the UN Global Compact. ${ }^{64}$

- Second, there are no overarching rules that determine or delimit the scope of application of each of those initiatives.

- Third, in a vertical type of pluralism, ${ }^{65}$ the GPs are also connected to national legislations, when they emphasize the state's obligation to protect human rights, and to provide state-based remedies to the victims. In this particular point, we can identify a hybrid model, in which the soft law of the GPs is combined and complemented by domestic hard law.

- Fourth, the GPs engage with both state and non-state actors. On the one hand, they involve corporations, when they encourage them to implement human rights due diligence processes (as an expression of their responsibility to respect them), and when they ask them to provide and participate in remedial mechanisms. ${ }^{66}$ On the other hand, although it is minimally, they also include the participation of civil society for the identification of risks, and as a participant in the remedial mechanisms. ${ }^{67}$

- Finally, the structure designed by the GPs satisfies the characteristics of a polycentric or experimentalist governance.$^{68}$ According to Char-

61 Ruggie, John Gerard, "Hierarchy or Ecosystem? Regulating Human Rights Risks of Multinational Enterprises”, in Rodríguez Garavito, César (ed.), Business and Human Rights: Beyond the End of the Beginning, Cambridge, Cambridge University Press, 2017, p. 44.

62 Idem. As we said, those systems comprise public, corporate and civil governance, at the international and national level.

63 Krisch, Nico, op. cit., p. 9.

${ }^{64}$ Choudhury, Barnali, op. cit., p. 967.

65 Krisch, Nico, op. cit., p. 13.

66 United Nations Guiding Principles on Business and Human Rights (2011), principles 3 and 25 .

67 Idem.

68 Rodríguez Garavito, César, "Business and Human Rights...”, op. cit., p. 41. 
les Sabel and Jonathan Zeitlin, and experimentalist governance is characterized by (i) the establishment of open-ended goals, (ii) the participation of a wide array of actors in order to achieve such objectives, (iii) a horizontal interrelation between actors and regulatory systems, (iv) and by a constant improvement process. ${ }^{69}$ In this case, the purpose of the GPs is to orient public, corporate and civil governance towards the safeguard of human rights. ${ }^{70}$ As well, the achievement of this goal is entrusted to several actors, such as states, business enterprises and civil society. ${ }^{71}$ Moreover, according to the GPs, corporations have the responsibility to communicate progress on the implementation of human rights due diligence processes ${ }^{72}$ so the public and corporate governance can be constantly reviewed..$^{73}$

Consequently, the main characteristics of a divergent approach of global law are present in the regulation of business and human rights. This alternative was followed by the SRSG because it was imperative to lay down a regulation in this field, and it was preferable to conceive it in a divergent fashion, as it had to be flexible enough to deal with the challenges posed by globalization, and because, at that moment, a convergent approach, akin to the one of the Norms, would not have obtained the endorsement of the UN. ${ }^{74}$

Nevertheless, the GPs have been strongly criticized because, as Christine Parker and John Howe argue, the safeguard of human rights cannot be conditioned to corporate goodwill. ${ }^{75}$ Therefore, many human rights professionals have insisted on a convergent alternative, such as a binding treaty on business and human rights and the establishment of an international human

69 Búrca, Gráinne de, "Experimentalism and the Limits of Uploading: The EU and the UN Disability Convention”, in Zeitlin, Jonathan (ed.), Extending Experimentalist Governance? The European Union and Transnational Regulation, Oxford, Oxford University Press, 2015, p. 298.

70 United Nations Guiding Principles on Business and Human Rights (2011), general principles.

71 Idem.

72 Ibidem, principle 21

73 Ibidem, principle 17 (c).

74 Ruggie, John Gerard, “Hierarchy or Ecosystem? Regulating...”, op. cit., p. 48.

75 Parker, Christine and Howe, John, "Ruggie's Diplomatic Project and its Missing Regulatory Infrastructure”, in Mares, Radu (ed.), The UN Guiding Principles on Business and Human Rights, Leiden, Martinus Nijhoff Publishers, 2012, p. 273. 
rights court. ${ }^{76}$ In the following section, we will study and assess the characteristics of this convergent initiative.

\section{The Convergent Proposal for a Treaty on Business and Human Rights}

In June 2014, following a proposal from Ecuador and South Africa, the UN Human Rights Council approved the creation of an intergovernmental working group with the mandate of elaborating a legally binding treaty to regulate the adverse impact of corporations on human rights. ${ }^{77}$ The supporters of this instrument argued that, due to the centrality of this issue, it was necessary to produce a mandatory initiative with the same normative strength as the ones that exist in the field of trade and investment. ${ }^{78}$ As well, they considered that, without the binding effect and enforceability of the obligations, the protection and respect of human rights would be sporadic and inconsistent, as they would depend on the good intentions of corporations. ${ }^{79}$ Moreover, as David Bilchitz argues, the creation of a binding treaty is necessary to clarify the obligations of corporations, create direct legal actions against them and serve as a reference for the development of domestic legislation. ${ }^{80}$

However, the critics of this initiative highlight the difficulty and unfeasibility of negotiating and adopting a treaty, due to the lack of political will of the states for doing so. ${ }^{81}$ In this sense, the considerable amount of time and effort dedicated to the business and human rights treaty might become futile, if it is very unlikely that countries will endorse the final project. ${ }^{82}$

76 See Deva, Surya and Bilchitz, David (eds.), Building a Treaty on Business and Human Rights: Context and Contours, Cambridge, Cambridge University Press, 2017.

77 Bilchitz, David, "Introduction: Putting Flesh on the Bone”, in Deva, Surya and Bilchitz, David (eds.), Building a Treaty on Business and Human Rights: Context and Contours, Cambridge, Cambridge University Press, 2017, p. 7.

78 Nolan, Justine, “A Business and Human Rights Treaty”, in Baumann-Pauly, Dorothée and Nolan, Justine (eds.), Business and Human Rights: From Principles to Practice, Melbourne, Routledge, 2016, p. 95.

79 Idem.

80 Ibidem, p. 97.

81 Idem. The expectation that corporations should respect human rights is still recent, so it has not yet obtained the international consensus to be considered as a legal obligation.

82 Ibidem, p. 95. As it happened to the Norms, which were rejected by the former UN Human Rights Commission. 
Moreover, as John Gerard Ruggie considers, the binding human rights treaties that have been adopted until now have not proven to be entirely successful. ${ }^{83}$ On the contrary, the Human Rights Council, through the Universal Periodic Review, and the different treaty-committees, are struggling to comply with their monitoring duties, even when they are focused on specific sets of human rights and a limited number of countries. ${ }^{84}$ Consequently, in this field, the task will be even more challenging, since there will be an uncountable number of corporations whose obligations in regards to the whole catalog of human rights must be supervised. ${ }^{85}$

On another note, there is still no consensus on the scope of the treaty. ${ }^{86}$ Concerning the regulatory targets, there is debate around the type of corporations that will be considered as duty-bearers. ${ }^{87}$ Different alternatives are under review: a treaty directed to all types of corporations, an instrument focused solely on transnational enterprises, or even several covenants addressing companies by commercial sector. ${ }^{88}$ As well, in regards to which human rights should be included in this initiative, several options are being studied, from a treaty focused exclusively on gross human rights violations, or an ambitious project that involves all the internationally recognized human rights. ${ }^{89}$

Another pending issue is related to the institutional scaffolding that will be necessary to ensure compliance with the business and human rights treaty. Will it follow the traditional reporting-monitoring mechanism of the treaty-committees? Or will it be a Human Rights Court, similar to the International Criminal Court, in charge of adjudicating claims against corporations for human rights violations? In any case, binding obligations require a body that ensures their fulfillment with the ability to impose enforceable sanctions. Consequently, the institutional structure will likely adopt a verti$\mathrm{cal}$ and hierarchical form, in line with the characteristics of the convergent approach of global law. ${ }^{90}$

83 Ruggie, John Gerard, Just Business..., cit., p. 60.

84 Idem.

85 Ibidem, p. 64.

86 Deva, Surya, "Scope of the Proposed Business and Human Rights Treaty", in Deva, Surya and Bilchitz, David (eds.), Building a Treaty on Business and Human Rights: Context and Contours, Cambridge, Cambridge University Press, 2017, p. 154.

87 Idem.

88 Ibidem, p. 155.

89 Idem.

90 Walker, Neil, op. cit., p. 55. 
Hence, the question here is to determine if the proposal of a treaty on business and human rights, as a convergent approach, is inevitably incompatible with the divergent approach proposed by the GPs. In the next section we will argue, first, that the convergent and divergent approaches of global law are compatible and, thus, they can coexist in the field of business and human rights. And second, we will identify the types of interactions that happen between them, as well as the contribution that one approach can make to the other, to achieve the objective that both have in common: the protection of human rights against corporate abuse.

\section{The COMPATIBILITY AND INTERACTION BETWEEN DiVERGENT and Convergent Approaches of Global LaW in the Field OF BUSINESS AND HUMAN RigHTS}

In this chapter, we will justify that the GPs are compatible and can coexist with the proposed treaty on business and human rights. Then, after analyzing the different exchanges that occur between them, we will argue that, in the field of business and human rights, the divergent approach, far from being an obstacle, constitutes a necessary starting point for future convergent developments.

\section{Compatibility}

Currently, we are experiencing an expansion of the field of human rights. ${ }^{91}$ This expansion is not only related to the creation of new rights at the universal and regional systems (such as the rights of persons with disabilities or the rights of indigenous peoples), or to the incorporation of different duty-bearers (as it currently happens with corporations). ${ }^{92}$ This enlargement is also associated with the adoption of new forms of regulation and adjudication, which move beyond the traditional top-down procedures, as it is the case of the GPs. ${ }^{93}$ Thus, in the view of César Rodríguez Garavito, both the old and

91 Rodríguez Garavito, César, “The Future of Human Rights...”, op. cit., p. 505.

92 Idem.

93 Idem. 
new elements are now coexisting and horizontally interrelating with each other, as if they were living species in an ecosystem..${ }^{94}$ Consequently, rather than competing and excluding one another, they must create symbiotic and mutually reinforcing relations among themselves. ${ }^{95}$

In this sense, in the regulatory model proposed by the GPs, voluntary and mandatory initiatives are not mutually excluding features. ${ }^{96}$ On the contrary, the GPs require that new strategies be built upon that common platform, regardless if they are conceived in a divergent or convergent fashion. Moreover, as John Gerard Ruggie affirms, the GPs are not a silver bullet capable to solve all problems. ${ }^{97}$ Consequently, they should not be considered as a finished work, but rather as the point of departure for new strategies, even for the long-term proposal of a binding treaty. ${ }^{98}$

This situation can be considered as a facet of horizontal legal pluralism, ${ }^{99}$ in which, at the international level, the overlapping systems established by different sources (namely the GPs and the treaty), can perfectly coexist. And although it is troublesome to determine which regime should prevail in governing a particular case, this problem is not uncommon to many areas of international law and, consequently, it does not prevent the coexistence of different systems in the same time and regulatory space. ${ }^{100}$

Once we have determined the compatibility of the convergent and divergent approaches in the field of business and human rights, let us now continue with the analysis of the interaction that occurs between them, as well as the positive outcomes that this relation brings about.

\section{Learning}

The first relation that can be identified in the field of business and human rights is related to the knowledge that the divergent approach acqui-

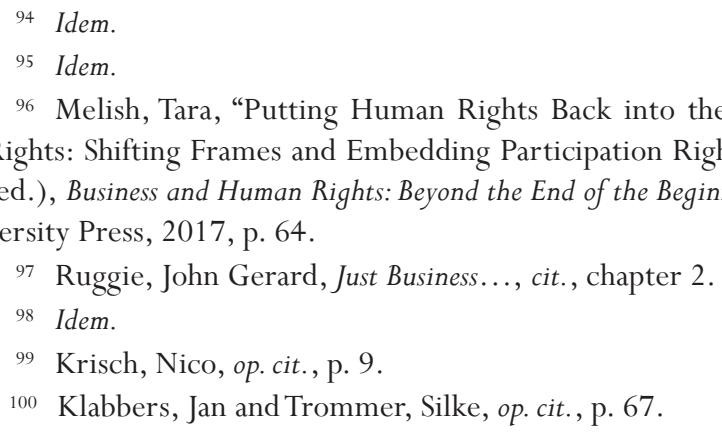


red from the previous convergent proposals. In this sense, let us illustrate this statement.

In chapter III of this essay, we mentioned that the elaboration of the GPs was preceded by the failed attempt of adopting the Norms on the Responsibilities of Transnational Corporations and other Business Enterprises with Regard to Human Rights (the Norms). ${ }^{101}$ We also said that the large majority of the states rejected this initiative because, among other reasons, it was conceived in a convergent fashion, with binding obligations articulated trough a stiff and hierarchical scaffolding. ${ }^{102}$ Consequently, during the drafting process of the GPs, John Gerard Ruggie took into account the features that determined the misfortune of the Norms, and with that in mind, he decided to take a different road towards the same goal. ${ }^{103}$

As well, he learned from other failed initiatives with convergent characteristics, such as the 1997 Kyoto Protocol on climate change. In particular, he noticed that the convergent attributes of the Kyoto Protocol, which set commitment targets with legal force, were less effective than the divergent features of the Paris Agreement, which is based on voluntary pledges by the states. ${ }^{104}$ In this sense, after analyzing the political will of the states and the limitations of the convergent approaches regarding contemporary problems, John Gerard Ruggie decided to adopt a divergent and pragmatic position through which it was possible to achieve a novel regulation in this field. ${ }^{105}$

\section{Preparation}

Occasionally, the adoption of a divergent approach is the first step towards the future implementation of a convergent initiative, and vice versa, since both of them "can be vehicles for focusing consensus on rules and principles, and for mobilizing a consistent, general response on the part of states". ${ }^{106}$ As well, as Jutta Brunnée and Stephen Toope suggest, "legal norms can only

101 Alston, Philip and Goodman, Ryan, op. cit., p. 1468.

102 Idem.

103 Ruggie, John Gerard, Just Business..., cit., p. xi.

104 Ruggie, John Gerard, “Global Governance...”, op. cit., p. 8.

105 Ruggie, John Gerard, Just Business..., cit., p. xlii.

106 Simmons, Penelope, "The Value-Added of a Treaty to Regulate Transnational Corporations and Other Business Enterprises”, in Deva, Surya and Bilchitz, David (eds.), Building a 
arise from social norms based on shared understandings". ${ }^{107}$ Consequently, "there is no possibility of simply imposing significant social change by fiat in the absence of some degree of social consensus, expressed in practice". ${ }^{108}$

In this sense, within the field of business and human rights, the initiatives that preceded the development of the GPs (such as the Norms on the Responsibilities of Transnational Corporations and other Business Enterprises with Regard to Human Rights), prepared the conditions that led to their endorsement by the UN Human Rights Council. Such initiatives began to sensitize the global community about the need to regulate, at the international level, the impact of business on human rights. Consequently, all of them contributed to creating shared understandings, which were essential for the adoption of the GPs.

In the same way, the current implementation of the GPs is also preparing the conditions for the future adoption of a binding treaty. Perhaps by the end of the last century, the topic of business and human rights was still new and, consequently, there was no political will to accept a binding initiative like the Norms. However, after the rejection of this proposal, there was at least sufficient consensus to approve the GPs, as a divergent alternative. Consequently, now is the turn of the GPs to strengthen social expectations, continue building consensus, demonstrate the benefits of regulating the behavior of corporations in regard to human rights, and justify to the international community the necessity to move forward in this field with the negotiation and adoption of a binding treaty or another alternative.

In this regard, and to continue with the progressive implementation of a binding initiative, as Penelope Simmons proposes, the next step should be to negotiate a framework treaty on business and human rights, "based on a reduced set of initial commitments", so it can be more easily adopted by the states. ${ }^{109}$ After doing so, this reduced treaty will continue to generate collective agreement on the necessity of a comprehensive instrument, for which nowadays there are not proper conditions and, therefore, "it cannot be accomplished overnight". ${ }^{110}$

Treaty on Business and Human Rights: Context and Contours, Cambridge, Cambridge University Press, 2017, p. 56.

107 Brunnée, Jutta and Toope, Stephen, op. cit., p. 15.

108 Ibidem, p. 159.

109 Simmons, Penelope, op. cit., p. 56.

110 Idem. 
In sum, what we demonstrate in this section is that the interaction between the convergent and divergent approaches of global law can be mutually beneficial, since each of them contributes to create and maintain the conditions of existence of the other. In the field of business and human rights, the failure of a convergent proposal gave way to the implementation of a divergent initiative, which is now preparing the terrain again for future convergent developments.

\section{Collaboration}

In the previous section, we reviewed how the GPs, as a divergent approach, can be complemented in the future by a convergent treaty on business and human rights. However, divergent initiatives do not necessarily grow to adopt convergent features. They can continue being divergent and collaborate with other convergent proposals to achieve common objectives.

Indeed, the transformation of the GPs into a treaty on business and human rights is just one option. However, another alternative is to adopt a hybrid model, a middle point between convergence and divergence, where the international treaty and the GPs coexist and collaborate. ${ }^{11}$

The failure of the previous convergent proposals demonstrate that comprehensive initiatives face strong resistance from the states. Therefore, from a pragmatic standpoint, the adoption of a binding instrument would be more viable if it is narrow in scope. ${ }^{112}$ This issue is determined by two aspects: the types of companies to which the treaty should apply and the types of human rights that it should cover. ${ }^{113}$ In this sense, the treaty can be limited exclusively to the regulation of transnational companies and gross human rights violations. ${ }^{114}$ Thus, the possibilities of being adopted would be higher, and the scope of protection could be complemented by the GPs, which involve all types of corporations (regardless their size, sector or areas of operation), and encompass any violation of human rights recognized by the UDHR, the ICCPR, the ICESCR and the principles determined by the ILO in the Declaration on Fundamental Principles and Rights at Work. ${ }^{115}$

111 Deva, Surya and Bilchitz, David (eds.), op. cit., p. 172.

112 Idem.

113 Deva, Surya, "Scope of the Proposed...", op. cit., p. 154.

114 Idem.

115 United Nations Guiding Principles on Business and Human Rights (2011), principle 12. 
A similar approach is being discussed by the UN Working Group on Business and Human Rights. Although article 3 of the revised draft of the treaty establishes that it shall cover all human rights and apply to all types of corporations, it gives particular emphasis to the ones of transnational character. ${ }^{116}$ We are still far from the adoption of the treaty, but the prevalent idea is that it cannot be an all-encompassing instrument. ${ }^{117}$ In this sense, and although the current scope of the revised draft can still be narrowed, the trend leads to a hybrid model in which the areas that cannot be governed by the treaty will be regulated by the GPs.

On another note, in a pluralist environment, the divergent and convergent approaches, that is the GPs and the international treaty, can collaborate as a whole, from the international arena, to set standards and shape the production of domestic legislation to minimize the impact of corporations on human rights. Consequently, they can also function as an authoritative reference for the internalization of international norms. ${ }^{118}$

In sum, in this chapter we have justified that initiatives with convergent and divergent characteristics can collaborate, and that it is precisely in this point where, after the learning and preparation processes, the compatibility and interaction of both visions can be best represented. Let us now expose the conclusions of this essay.

\section{CONCLUSIONS}

After analyzing the convergent and divergent approaches of global law within the field of business and human rights, we demonstrated that these two different conceptions are not incompatible, since they can perfectly coexist in a particular time and regulatory space.

116 UN Working Group on Business and Human Rights, "Revised Draft of the Legally Binding Instrument to Regulate International Human Rights Law, the Activities of Transnational Corporations and Other Business Enterprises”, 2019, available at: https: / /www.ohchr.org/Docu ments /HRBodies/HRCouncil/WGTransCorp/OEIGWG_RevisedDraft_LBI.pdf.

117 The current discussions on the proposed treaty can be followed in Business and Human Rights Resource Centre, “UN Intergovernmental Working Group on Proposed Treaty”, 2020, available at: https: / / www.business-humanrights.org/en/un-intergovt-working-group-on-proposed-treaty.

118 Brunnée, Jutta and Toope, Stephen, op. cit., p. 116. 
As well, the development of the initiatives that have been proposed to regulate the impact of business on human rights, shows how the convergent and divergent approaches have interacted in the past. For example, the knowledge obtained from the failed experiences of the convergent proposals was central for the development of the GPs, as a divergent and innovative strategy in this field. As well, each of the initiatives has contributed to create and maintain the conditions of existence of one another. The adoption of the GPs would have been impossible without the previous rejection of the Norms, and the possible adoption of a binding treaty would be unthinkable without the current implementation of the GPs. Moreover, the collaboration between these two visions of global law might bring about suitable solutions in the field of business and human rights, by adopting hybrid models that conjugate the implementation of a binding treaty, with a narrow approach, and the operation of the GPs that have a wider scope.

Finally, and perhaps more important, this article is a call to move beyond the debate about the differences, and focus our attention in the coincidences and positive interactions that can occur between these two approaches of global law, since this is an underexplored area in which further research is needed.

\section{BIBLIOGRAPHY}

Alston, Philip, "The Not-A-Cat Syndrome: Can the International Human Rights Regime Accommodate Non-State Actors?", in Alston, Philip (ed.), Non-State Actors and Human Rights, Oxford, Oxford University Press, 2005.

Alston, Philip and Goodman, Ryan, International Human Rights, Oxford, Oxford University Press, 2013.

Bilchitz, David, "Introduction: Putting Flesh on the Bone", in DeVA, Surya and BilchitZ, David (eds.), Building a Treaty on Business and Human Rights: Context and Contours, Cambridge, Cambridge University Press, 2017.

BODANSKY, Daniel, "Climate Change: Transnational Legal Order or Disorder?”, in Halliday, Terrence and SHAFFER, Gregory (eds.), Transnational Legal Orders, Cambridge, Cambridge University Press, 2015. 
Esta revista forma parte del acervo de la Biblioteca Jurídica Virtual del Instituto de Investigaciones Jurídicas de la UNAM

BRUnNÉE, Jutta and TOOPE, Stephen, Legitimacy and Legality in International Law: An Interactional Account, Cambridge, Cambridge University Press, 2010.

BúrCA, Gráinne de, "Experimentalism and the Limits of Uploading: The EU and the UN Disability Convention”, in ZEITLIN, Jonathan (ed.), Extending Experimentalist Governance? The European Union and Transnational Regulation, Oxford, Oxford University Press, 2015.

BúrCA, Gráinne de et al., "New Modes of Pluralist Global Governance”, New York University Journal of International Law and Politics, New York, vol. 45, no. 1, 2013.

Business AND Human Rights ResourCE CENTRE, “UN Intergovernmental Working Group on Proposed Treaty”, 2020, available at: https: / / www. business-humanrights.org/en/un-intergovt-working-group-on-proposed-treaty.

CHoudhury, Barnali, "Balancing Soft and Hard Law for Business and Human Rights", International and Comparative Law Quarterly, Cambridge, vol. 67, no. 4, 2018.

DEVA, Surya, "Scope of the Proposed Business and Human Rights Treaty", in DEva, Surya and Bilchitz, David (eds.), Building a Treaty on Business and Human Rights: Context and Contours, Cambridge, Cambridge University Press, 2017.

DeVA, Surya and Bilchitz, David (eds.), Building a Treaty on Business and Human Rights: Context and Contours, Cambridge, Cambridge University Press, 2017.

Klabbers, Jan and Trommer, Silke, "Peaceful Coexistence: Normative Pluralism in International Law", in KLABBERS, Jan and PIIPARINEN, Touko (eds. ), Normative Pluralism and International Law: Exploring Global Governance, Cambridge, Cambridge University Press, 2013.

KRISCH, Nico, "Pluralism in Postnational Risk Regulation: The Dispute over GMOs and Trade", Transnational Legal Theory, London, vol. 1, 2010.

MELISH, Tara, "Putting Human Rights Back into the UNGP on Business and Human Rights: Shifting Frames and Embedding Participation Rights", in Rodríguez Garavito, César (ed.), Business and Human Rights: Beyond the End of the Beginning, Cambridge, Cambridge University Press, 2017.

Nolan, Justine, "A Business and Human Rights Treaty”, in BAUMANn-PAULY, Dorothée and Nolan, Justine (eds.), Business and Human Rights: From Principles to Practice, Melbourne, Routledge, 2016. 
NOLLKAEMPER, Andre, "Inside or Out: Two Types of International Legal Pluralism”, in KLABbers, Jan and PIIPARINEN, Touko (eds.), Normative Pluralism and International Law: Exploring Global Governance, Cambridge, Cambridge University Press, 2013.

PARKER, Christine and Howe, John, "Ruggie's Diplomatic Project and its Missing Regulatory Infrastructure”, in MARES, Radu (ed.), The UN Guiding Principles on Business and Human Rights, Leiden, Martinus Nijhoff Publishers, 2012.

Rodríguez Garavito, César, "Business and Human Rights: Beyond the End of the Beginning”, in Rodríguez Garavito, César (ed.), Business and Human Rights: Beyond the End of the Beginning, Cambridge, Cambridge University Press, 2017.

Rodríguez Garavito, César, "The Future of Human Rights: From Gatekeeping to Symbiosis", SUR International Journal on Human Rights, São Paulo, vol. 11, no. 20, 2014.

RuGGIE, John Gerard, "Global Governance and New Governance Theory: Lessons from Business and Human Rights", Global Governance, Boston, vol. 20, 2014.

RuGGIE, John Gerard, "Hierarchy or Ecosystem? Regulating Human Rights Risks of Multinational Enterprises", in RODRíGUEZ GARAVITO, César (ed.), Business and Human Rights: Beyond the End of the Beginning, Cambridge, Cambridge University Press, 2017.

RugGiE, John Gerard, Just Business: Multinational Corporations and Human Rights, New York, Norton and Company, 2013.

Simmons, Penelope, “The Value-Added of a Treaty to Regulate Transnational Corporations and Other Business Enterprises", in DEVA, Surya and BILCHITZ, David (eds.), Building a Treaty on Business and Human Rights: Context and Contours, Cambridge, Cambridge University Press, 2017.

UN Working Group on Business and Human Rights, "Revised Draft of the Legally Binding Instrument to Regulate International Human Rights Law, the Activities of Transnational Corporations and Other Business Enterprises", 2019, available at: https: / /www.ohchr.org/Documents / HRBodies / HRCouncil /WGTransCorp/OEIGWG_RevisedDraft_LBI.pdf.

United NATiOns, "Global Compact”, 2020, available at: https: / /www.ungl obalcompact.org/.

United NATions, General AsSembly, "Fragmentation of International Law: Difficulties Arising from the Diversification and Expansion of Internatio- 
Esta revista forma parte del acervo de la Biblioteca Jurídica Virtual del Instituto de Investigaciones Jurídicas de la UNAM

nal Law", Report of the Study Group of the International Law Commission, A/CN.4/L.682, 13 April 2006.

WALKer, Neil, Intimations of Global Law, Cambridge, Cambridge University Press, 2014.

Weissbrodt, David and Kruger, Muria, "Human Rights Responsibilities of Business as Non-State Actors", in Alston, Philip (ed.), Non-State Actors and Human Rights, Oxford, Oxford University Press, 2005. 